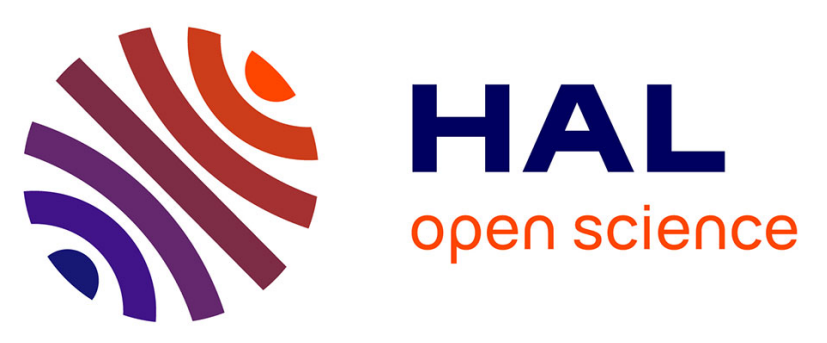

\title{
Powering reductive charge shift reactions-linking fullerenes of different electron acceptor strength to secure an energy gradient
}

Carmen Villegas, Juan Luis Delgado, Pierre-Antoine Bouit, Bruno Grimm, Wolfgang Seitz, Nazario Martín, Dirk M. Guldi

\section{To cite this version:}

Carmen Villegas, Juan Luis Delgado, Pierre-Antoine Bouit, Bruno Grimm, Wolfgang Seitz, et al.. Powering reductive charge shift reactions-linking fullerenes of different electron acceptor strength to secure an energy gradient. Chemical Science, 2011, 2 (9), pp.1677. 10.1039/C1SC00331C . hal02380078

\section{HAL Id: hal-02380078 https://hal.science/hal-02380078}

Submitted on 26 Nov 2019

HAL is a multi-disciplinary open access archive for the deposit and dissemination of scientific research documents, whether they are published or not. The documents may come from teaching and research institutions in France or abroad, or from public or private research centers.
L'archive ouverte pluridisciplinaire HAL, est destinée au dépôt et à la diffusion de documents scientifiques de niveau recherche, publiés ou non, émanant des établissements d'enseignement et de recherche français ou étrangers, des laboratoires publics ou privés. 


\section{Chemical Science}

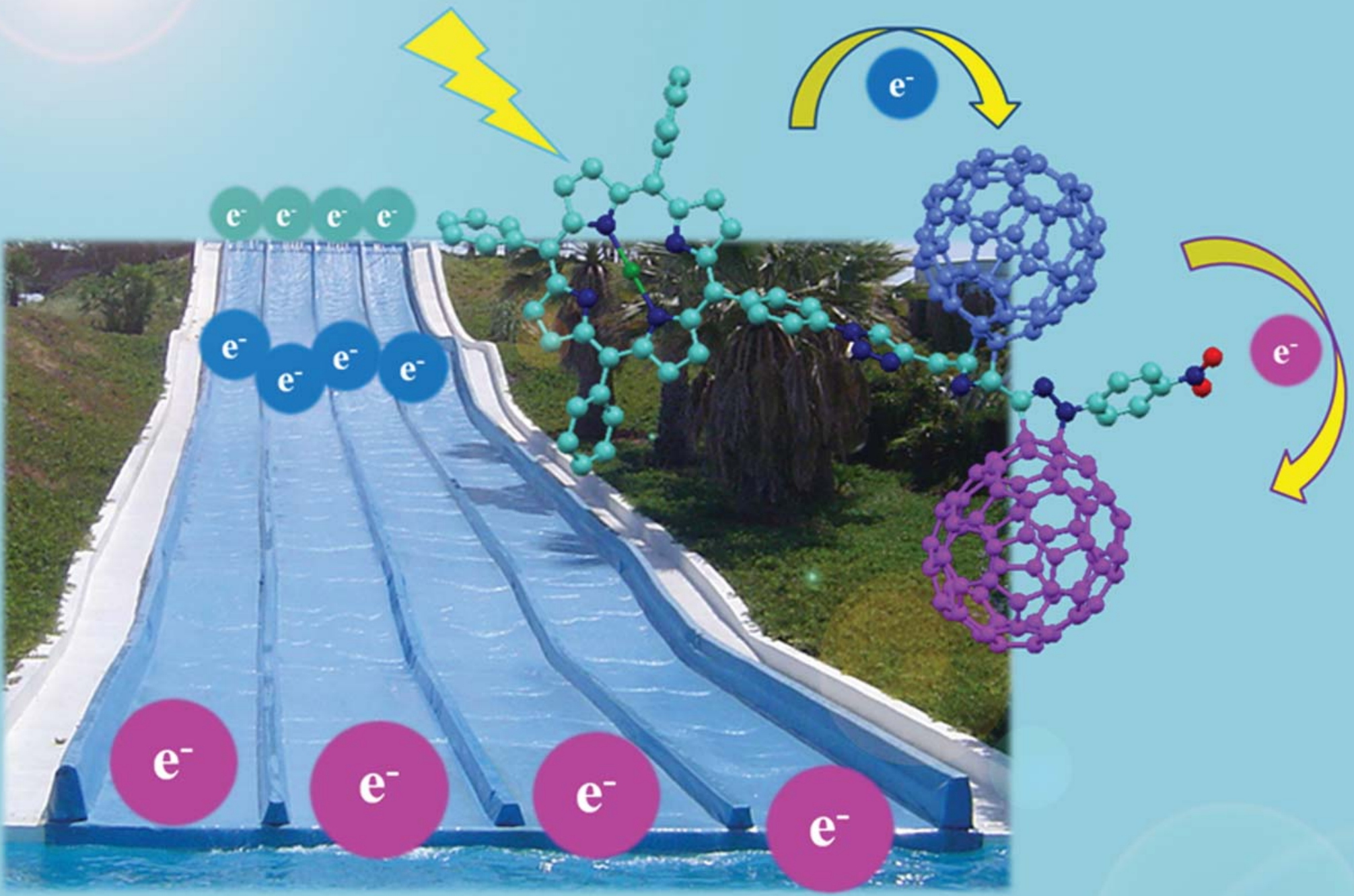




\title{
Powering reductive charge shift reactions-linking fullerenes of different electron acceptor strength to secure an energy gradient $\dagger$
}

\author{
Carmen Villegas, ${ }^{a}$ Juan Luis Delgado, ${ }^{a b}$ Pierre-Antoine Bouit, ${ }^{b}$ Bruno Grimm, ${ }^{c}$ Wolfgang Seitz, ${ }^{c}$ \\ Nazario Martín ${ }^{* a b}$ and Dirk M. Guldi ${ }^{* c}$
}

Received 27th May 2011, Accepted 15th June 2011

DOI: $10.1039 / \mathrm{c} 1 \mathrm{sc00331c}$

We report here on one of the rare cases that realizes a reductive charge shift from a primary electron acceptor $\left(\mathrm{C}_{60}\right)$ to a secondary electron acceptor $\left(\mathrm{C}_{70}\right)$ in a $\mathrm{ZnP}-\mathrm{C}_{60}-\mathrm{C}_{70}$ conjugate. Initially, charge separation evolves from an excited state electron donor $(\mathrm{ZnP})$. By far the most far reaching benefit from such a reductive pathway is a marked slow down of the energy wasting charge recombination when compared to the $\mathrm{ZnP}-\mathrm{C}_{60}$ conjugate (i.e., picoseconds versus nanoseconds).

\section{Introduction}

Nature employs a myriad of interlocking principles to create sophisticated and amazing architectures, in which a formidable level of control over organizing individual building blocks and replacing them has been realized. To this end, the structure of the bacterial photosynthetic reaction centers provides important incentives for arranging electron donors and electron acceptors. Sunlight is harvested by antenna chlorophylls before it is unidirectionally funneled to the special "bacteriochlorophyll dimer" pair. Here, excited state interactions in the form of an electron transfer yield an oxidized special "bacteriochlorophyll dimer", while the electrons are inserted into a redox chain. Importantly, a directed cascade of electron transfer reactions mediates the electrons through the well-balanced redox gradients in the redox chain and retards the charge separation. ${ }^{1}$

Fullerenes are readily available and exhibit exciting characteristics. ${ }^{2}$ For example, the delocalization of charges within the giant, spherical carbon framework together with the rigid, confined structure of the $\pi$-sphere offers unique opportunities for stabilizing charged entities. ${ }^{3}$ Above all, the small reorganization energies of fullerenes in charge-transfer reactions have led to a notable breakthrough in multicomponent electron donoracceptor systems by providing accelerated charge separation and

${ }^{a}$ Departamento de Química Orgánica, Facultad de Ciencias Químicas, Universidad Complutense de Madrid, Ciudad Universitaria s/n, 28040 Madrid, Spain.E-mail: nazmar@quim.ucm.es; Fax: (+34) 91-394-4103; Tel: (+34) 91-394-4227

${ }^{b} I M D E A$-Nanociencia, Facultad de Ciencias, Módulo C-IX, $3^{a}$ planta, Ciudad Universitaria de Cantoblanco, 28049 Madrid, Spain

${ }^{c}$ Department of Chemistry and Pharmacy \& Interdisciplinary Center of Molecular Materials (ICMM) Friedrich-Alexander-University ErlangenNuremberg Egerlandstr. 3, 91058 Erlangen, Germany. E-mail: dirk. guldi@chemie.uni-erlangen.de; Fax: (+49) 9131-85-28307

$\dagger$ Electronic supplementary information (ESI) available: Synthetic procedure, and complete characterizations of all the new compounds. See DOI: $10.1039 / \mathrm{c} 1 \mathrm{sc} 00331 \mathrm{c}$ decelerated charge recombination. ${ }^{4}$ In most of such multicomponent systems, photoexcitation is the inception to reduce the electron accepting fullerenes and to generate a hole at the electron donor. A redox gradient governs a hole transfer from the primary electron donor to the secondary electron donor, etc. ${ }^{5}$

In general, there have been only a small number of multicomponent electron donor-acceptor systems, in which a unidirectional flow of electrons evolves and, in turn, mediates electrons between different electron acceptors rather than holes between different electron donors. ${ }^{6}$ This is what the current work addresses. In particular, we present a paradigm shift by using two fullerenes that are covalently linked to each other and an excited state electron donating $\mathrm{ZnP}$ - see Chart 1 . To ensure an unambiguous characterization of the electron transfer pathways, two different fullerenes, that is, $\mathrm{C}_{60}$ and $\mathrm{C}_{70}$, were chosen. Implementation of a redox gradient was realized by using different fullerene functionalization. In particular, a fulleropyrrolidine of $\mathrm{C}_{60}$ and a fulleropyrazoline of $\mathrm{C}_{70}$ - to improve the electron
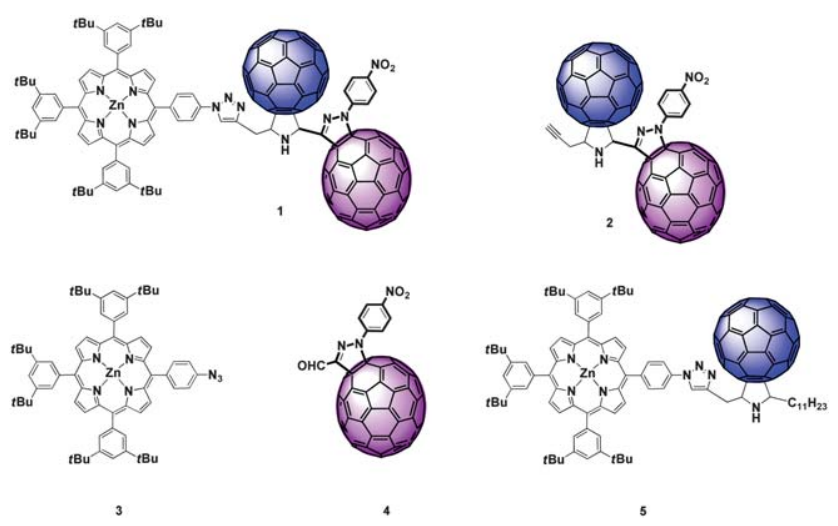

Chart 1 Structure of $\mathrm{ZnP}-\mathrm{C}_{60}-\mathrm{C}_{70}$ (1), $\mathrm{C}_{60}-\mathrm{C}_{70}$ (2), $\mathrm{ZnP}$ azide (3), formyl containing 2-pyrazolino[70]fullerene (4) and $\mathrm{ZnP}-\mathrm{C}_{60}$ (5). Compounds 1, 2, $\mathbf{4}$ and $\mathbf{5}$ were obtained as isomeric mixtures. 
acceptor character-served as primary and secondary electron acceptor, respectively.

\section{Results and discussion}

The synthesis of $\mathbf{1}$ has been carried out by means of copper catalyzed "click-chemistry" of fullerene dimer (2) with zinc porphyrine azide $(3)^{7}$ in moderate yields $(40 \%){ }^{8} 2$, on the other hand, was formed by reacting formyl containing 2-pyrazolino[70] fullerene (4) ${ }^{9}$ with 2-propargyl-glycine and $\mathrm{C}_{60}$ (57\% yield). ${ }^{10}$ Finally, as a reference system, we have synthesized $\mathbf{5}$ bearing only one fragment of $\mathbf{1}$, following a similar methodology. ${ }^{8,11}$ It is worth mentioning that compounds $\mathbf{1}, \mathbf{2}$, and $\mathbf{4}$ were obtained as a mixture of isomers stemming from the difference site and regioselectivity in the cycloaddition reaction on the $\mathrm{C}_{70}$ fullerene. ${ }^{12}$

$\mathbf{1}$ displays in THF (Figure $\mathrm{S} 1 \dagger$ ) the absorption characteristics of $\mathrm{C}_{60}$ and $\mathrm{C}_{70}$ at $253 / 315$ and $360 / 465 \mathrm{~nm}$, respectively. The presence of the Soret- and Q-bands of $\mathrm{ZnP}$ at 426 and 557/597 $\mathrm{nm}$ complete the characterization of $\mathbf{1}$. A closer inspection reveals, however, that the absorption spectrum of $\mathbf{1}$ fails to resemble the sum of the individual spectra, that is, $\mathbf{2}$ and $\mathbf{3}$.

\section{Electrochemistry}

The electrochemical properties of 1-3 have been investigated by means of room temperature cyclic voltammetry/osteryoung square wave voltammetry experiments (Figure S3, Table S1 $\dagger$ ). For 3, the first oxidation process occurs at 0.52 to yield the $\mathrm{ZnP}$ radical cation. The $\mathrm{ZnP}$ dication, on the other hand is formed at $0.90 \mathrm{~V}$. Reduction processes at -1.84 and $-2.00 \mathrm{~V}$ relate to the reduction of $\mathrm{ZnP}$ to the corresponding radical anion and dianion, respectively. At $-1.62 \mathrm{~V}$, the reduction of the azide fragment set in. In principle, $\mathrm{C}_{60}$ and $\mathrm{C}_{70}$ exhibit nearly identical reduction processes. ${ }^{13}$ In 2 , however, the electron withdrawing effects of the pyrazoline ring ${ }^{14}$ shifts the $C_{70}$ reduction processes of the fulleropyrazoline to $-0.72,-1.13,-1.50$, and $-1.87 \mathrm{~V}$. The $\mathrm{C}_{60}$ reduction processes of the fulleropyrrolidine are cathodically shifted that are detectable at $-0.85,-1.26,-1.64$, and $-2.02 \mathrm{~V} .1$ shows two oxidation processes at 0.52 and $0.89 \mathrm{~V}$ to lead to the $\mathrm{ZnP}$ radical cation and $\mathrm{ZnP}$ dication. On the reductive side, several redox processes are noted. Whereas the reduction of the fulleropyrazoline of $\mathrm{C}_{70}$ involves processes at $-0.72,-1.13,-1.52$, and $-1.86 \mathrm{~V}$, reduction of the fulleropyrrolidine of $\mathrm{C}_{60}$ is seen at $-0.85,-1.25,-1.62$, and $-2.01 \mathrm{~V}$ generating the $\mathrm{C}_{70} / \mathrm{C}_{60}$ radical anion, the $\mathrm{C}_{70} / \mathrm{C}_{60}$ dianion, the $\mathrm{C}_{70} / \mathrm{C}_{60}$ trianion, and the $\mathrm{C}_{70} / \mathrm{C}_{60}$ tetraanion, respectively. The reduction of $\mathrm{ZnP}$ to the corresponding radical anion and dianion at -1.86 and $-2.01 \mathrm{~V}$, respectively, and the reduction of the triazole at $-1.62 \mathrm{~V}$ are superimposed to the reduction processes of $\mathrm{C}_{60}$ and $\mathrm{C}_{70}$ and intensity the reductive currents in the corresponding regions.

\section{Photophysical studies}

Transient absorption measurements in THF with the references were performed in the following order- $\mathrm{ZnP}(3)$, pyrrolidino[60] fullerene, and pyrazolino[70]fullerene (4) - before turning to the
$\mathrm{C}_{60}-\mathrm{C}_{70}$ (2) and $\mathrm{ZnP}-\mathrm{C}_{60}$ conjugates (5) and, finally, to the $\mathrm{ZnP}-$ $\mathrm{C}_{60}-\mathrm{C}_{70}$ conjugate (1).

When photoexciting the $\mathrm{ZnP}$ reference (3) at 420 or $550 \mathrm{~nm}$, within 2.0 ps the higher singlet excited state features of $\mathrm{ZnP}$ transform into those of the lowest singlet excited state. Specifically, characteristic maxima at 455, 580, and $630 \mathrm{~nm}$ as well as minima at 565 and $605 \mathrm{~nm}$ are clear attributes of the singletsinglet absorptions of $\mathrm{ZnP} .{ }^{15}$ On a time-scale of up to $3.0 \mathrm{~ns}$, the fate of the $\mathrm{ZnP}$ singlet excited state is dominated by intersystem crossing - driven by a strong spin-orbit coupling - to afford the corresponding triplet excited state $\left(2.1 \mathrm{~ns}-4.8 \times 10^{8} \mathrm{~s}^{-1}\right)$. The latter was identified by a long-lived $\left(100 \mu \mathrm{s}-1.0 \times 10^{4} \mathrm{~s}^{-1}\right)$ and strongly absorbing triplet-triplet transition that maximizes at 840 nm. $^{16}$

Excitation of the pyrrolidino[60]fullerene and pyrazolino[70] fullerene references at $387 \mathrm{~nm}$ or $550 \mathrm{~nm}$ (not shown) populates their singlet excited states with characteristic absorption maxima at $610 / 920$ and $610 / 1290 \mathrm{~nm}$, respectively. Both singlet excited states undergo intersystem crossing to the corresponding triplet manifolds with characteristic lifetimes of $1.4 \mathrm{~ns}\left(7.0 \times 10^{8} \mathrm{~s}^{-1}\right)$ for $\mathrm{C}_{60}$ and $0.97 \mathrm{~ns}\left(1.03 \times 10^{9} \mathrm{~s}^{-1}\right)$ for $\mathrm{C}_{70}$ as well as characteristic maxima at 700 and $970 \mathrm{~nm} \cdot{ }^{17}$

When conjugating $\mathrm{C}_{60}$ with $\mathrm{C}_{70}$, the transient absorption features that were recorded immediately upon photoexcitation of (2) are best described as the superimposition of the $\mathrm{C}_{60}$ and the $\mathrm{C}_{70}$ singlet excited states featuring maxima at 610/920 and 610/ $1290 \mathrm{~nm}$, respectively. Particularly interesting is the fact that the $\mathrm{C}_{60}$ singlet excited state decays in the presence of $\mathrm{C}_{70}$ with dynamics $\left(15\right.$ ps- $\left.6.0 \times 10^{10} \mathrm{~s}^{-1}\right)$ that are appreciably faster than those seen in the $\mathrm{C}_{60}$ reference. Owing to the shear impossibility of oxidizing $\mathrm{C}_{60}$ or $\mathrm{C}_{70}$ in the photochemical processes, the aforementioned seems to prompt an intramolecular transduction of singlet excited state energy from $\mathrm{C}_{60}$ to $\mathrm{C}_{70}$. In fact, the sole photoproduct decays with dynamics that resembles those seen for the intersystem crossing in the $C_{70}$ reference $(0.97 \mathrm{~ns}-1.03 \times$ $\left.10^{9} \mathrm{~s}^{-1}\right)$. Crucial support for the energy transfer notion comes from the observation that the only triplet excited state seen at time delays of $3.0 \mathrm{~ns}$ and beyond was that of $\mathrm{C}_{70}$ with its fingerprint absorption at $970 \mathrm{~nm} .{ }^{18}$ Our transient absorption measurements failed, on the other hand, to provide for $\mathbf{2}$ any appreciable evidence for the $700 \mathrm{~nm}$ maximum of the $\mathrm{C}_{60}$ triplet excited state. $^{19}$

Next, the transient absorption changes of the $\mathrm{ZnP}-\mathrm{C}_{60}$ conjugate (5) were recorded with several time delays after the $550 \mathrm{~nm}$ laser pulse and compared with those seen for the $\mathrm{ZnP}$ reference - see Fig. 1. At early times, these are practically identical to those of the $\mathrm{ZnP}$ reference, disclosing a strong maximum at $455 \mathrm{~nm}$ and a strong bleaching at $565 \mathrm{~nm}$. However, at delay times of around $10 \mathrm{ps}$, the $455 \mathrm{~nm}$ absorption starts to decay and simultaneously a new transition grows in the visible, that is, a maximum around $630 \mathrm{~nm}\left(50 \mathrm{ps}-2.0 \times 10^{10} \mathrm{~s}^{-1}\right)$, which is accompanied by a near-infrared feature, namely a $1005 \mathrm{~nm}$ maximum. Based on a spectral comparison with former spectroelectrochemical and pulse radiolytical investigations, ${ }^{20}$ we ascribe the earlier band to the $\mathrm{ZnP} \pi$-radical cation $\left(\mathrm{ZnP}^{+}\right)$, while the latter band corresponds to the $\mathrm{C}_{60} \pi$-radical anion $\left(\mathrm{C}_{60^{-}}\right)$. In accordance with these results, we propose that charge separation evolves from the $\mathrm{ZnP}$ singlet excited state to the electron accepting fullerene to yield $\mathrm{ZnP}^{+}-\mathrm{C}_{60} 0^{-}$. The absorption of the 

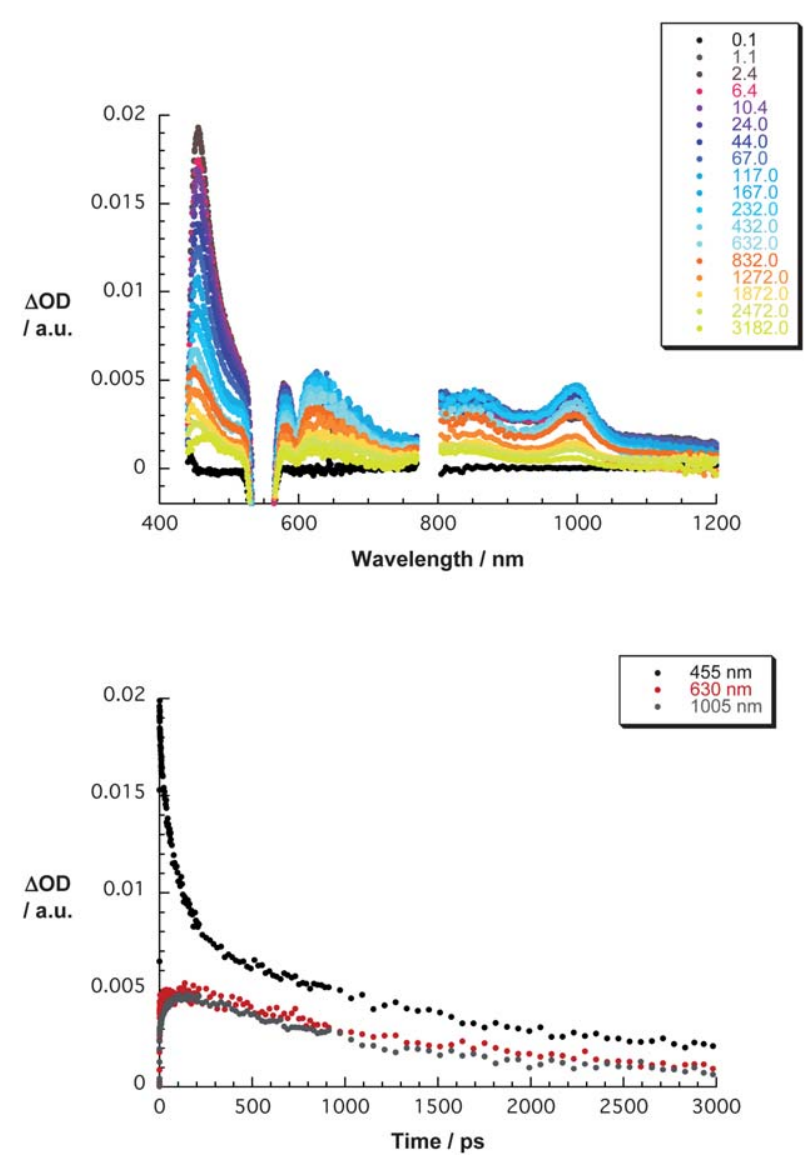

Fig. 1 Upper part - differential absorption spectra (visible and nearinfrared) obtained upon femtosecond flash photolysis $(550 \mathrm{~nm})$ of $\mathrm{ZnP}-$ $\mathrm{C}_{60}$ in THF with several time delays between 0 and 3000 ps at room temperature - see figure legend for time delays. Lower part-timeabsorption profiles of the spectra shown in the upper and central parts at 455, 630, and $1005 \mathrm{~nm}$ monitoring the charge separation and charge recombination.

$\mathrm{ZnP}^{+}-\mathrm{C}_{60}{ }^{-}$state decays in the nanosecond regime $(1.3 \mathrm{~ns}-7.6 \times$ $\left.10^{8} \mathrm{~s}^{-1}\right)$. Notable is that the semiflexible spacer connecting $\mathrm{ZnP}$ with $\mathrm{C}_{60}$ provides ample room for configurational changes in the $\mathrm{ZnP}-\mathrm{C}_{60}$ conjugate. Based on previous studies, such changes in configuration are likely to be the inception for through space rather than through bond electron transfer interactions. ${ }^{21}$

Finally, we turned to the $\mathrm{ZnP}-\mathrm{C}_{60}-\mathrm{C}_{70}$ conjugate (1) - see Fig. 2. Immediately upon $550 \mathrm{~nm}$ photoexcitation we noticed the characteristics of the $\mathrm{ZnP}$ singlet excited state in the visible and those of the $\mathrm{C}_{70}$ singlet excited state in the near-infrared with maxima at 455 and $1290 \mathrm{~nm}$, respectively. Both are, however, metastable and transform rapidly $\left(10 \mathrm{ps}-1.0 \times 10^{11} \mathrm{~s}^{-1}\right)$ into a new transient product. To this end, evidence for the $\mathrm{ZnP}$ $\pi$-radical cation $\left(\mathrm{ZnP}^{+}\right)$evolves in the visible region-550 to $800 \mathrm{~nm}$. Changes in the near-infrared region, namely at 1005 and 1315 , on the other hand, relate to the involvement of the $\mathrm{C}_{60} \pi$ radical anion $\left(\mathrm{C}_{60^{-}}\right)$and the $\mathrm{C}_{70} \pi$-radical anion $\left(\mathrm{C}_{70^{-}}\right)^{-22,23}$ Important is that at time delays of around $1.0 \mathrm{~ns}$, only the features of the $\mathrm{C}_{70} \pi$-radical anion $\left(\mathrm{C}_{70}{ }^{-}\right)$are discernable at $1315 \mathrm{~nm}$, while those of the $\mathrm{C}_{60} \pi$-radical anion $\left(\mathrm{C}_{60}{ }^{-}\right)$at 1005 $\mathrm{nm}$ have completely disappeared. From analyzing the $\mathrm{C}_{60}$
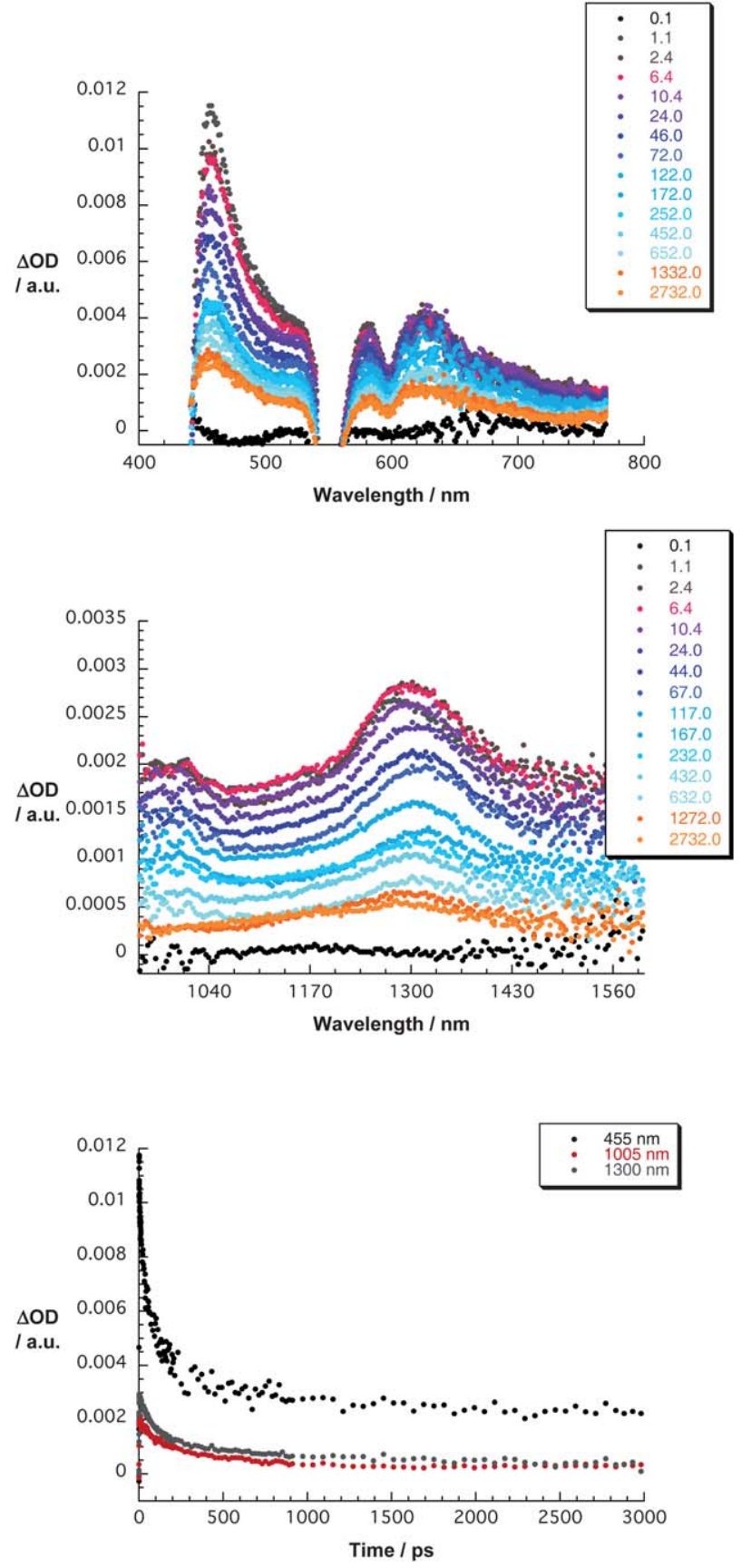

Fig. 2 Upper part - differential absorption spectra (visible) obtained upon femtosecond flash photolysis $(550 \mathrm{~nm})$ of $\mathrm{ZnP}-\mathrm{C}_{60}-\mathrm{C}_{70}$ in THF with several time delays between 0 and $3000 \mathrm{ps}$ at room temperature - see figure legend for time delays. Central part-differential absorption spectra (extended near-infrared) obtained upon femtosecond flash photolysis $(550 \mathrm{~nm})$ of $\mathrm{ZnP}-\mathrm{C}_{60}-\mathrm{C}_{70}$ in THF with several time delays between 0 and 3000 ps at room temperature - see figure legend for time delays. Lower part - time-absorption profiles of the spectra shown in the upper and central parts at 455, 1005, and $1300 \mathrm{~nm}$ monitoring the charge separation and charge shift.

$\pi$-radical anion $\left(\mathrm{C}_{60^{-}}{ }^{-}\right)$decay at, for example, $1005 \mathrm{~nm}$, we have determined a lifetime of 135 ps $\left(7.1 \times 10^{9} \mathrm{~s}^{-1}\right)$. A comparison with the intrinsic lifetime of $\mathrm{ZnP}^{+}-\mathrm{C}_{60} 0^{-}\left(1.3 \mathrm{~ns}-7.6 \times 10^{8} \mathrm{~s}^{-1}\right)$ leads us to conclude that the nature of the $\mathrm{ZnP}^{+}-\mathrm{C}_{60}{ }^{-}-\mathrm{C}_{70}$ decay 
is an exothermic and unidirectional charge shift, which involves an electron shift between the two electron accepting fullerenes. The correspondingly formed $\mathrm{ZnP}^{+}-\mathrm{C}_{60}-\mathrm{C}_{70}{ }^{-}$shows no appreciable decay in the 1100 to $1500 \mathrm{~nm}$ range on the $3.0 \mathrm{~ns}$ time scale. Such an impressive gain in stability is also substantiated when inspecting the visible region. Here, the $\mathrm{ZnP} \pi$-radical cation $\left(\mathrm{ZnP}^{+}\right)$, which absorbs between 550 and $800 \mathrm{~nm}$, is stable without showing any noticeable decay. From complementary nanosecond experiments a lifetime of $100 \pm 30 \mathrm{~ns}$-Figure S18 has been derived. As far as the $\mathrm{ZnP}^{+}-\mathrm{C}_{60}-\mathrm{C}_{70}{ }^{-}$quantum yield is concerned, a multiwavelength analysis reveals $30 \%$. One factor that may prevent higher quantum yields is the semiflexible spacer.

\section{Conclusions}

In short, a fulleropyrrolidine of $\mathrm{C}_{60}$ and a fulleropyrazoline of $\mathrm{C}_{70}$ have been integrated together with $\mathrm{ZnP}$ into a novel $\mathrm{ZnP}-$ $\mathrm{C}_{60}-\mathrm{C}_{70}$ conjugate towards creating a gradient of redox centers. In femtosecond flash photolysis studies we confirm fluorescence experiments that are not discussed and the occurrence of an electron transfer sequence. ${ }^{24}$ In particular, an initial charge separation yields $\mathrm{ZnP}^{+}-\mathrm{C}_{60}{ }^{-}-\mathrm{C}_{70}$-with a lifetime of one hundred picoseconds - and is followed by a subsequent charge shift to afford $\mathrm{ZnP}^{+}-\mathrm{C}_{60}-\mathrm{C}_{70}{ }^{-}$- with a lifetime of around one hundred nanoseconds. Overall, our finding constitutes one of the rare cases, in which reductive charge shift from a primary electron acceptor $\left(\mathrm{C}_{60}\right)$ to a secondary electron acceptor $\left(\mathrm{C}_{70}\right)$ retards charge recombination as opposed to the more common oxidative charge shift from primary to secondary donors.

\section{Acknowledgements}

Cluster of Excellence "Engineering of Advanced Materials" is gratefully acknowledged. This work has been supported by the MICINN of Spain (CT2008-00795, and Consolider-Ingenio CSD2007-00010 on Molecular Nanoscience), Comunidad de Madrid (MADRISOLAR-2, S2009/PPQ-1533) and EU (FUNMOLS FP7-212942-1). P.A.B. thanks IMDEA-Nanociencia for a postdoctoral research grant. J.L.D. thanks the MICINN of Spain for a Ramón y Cajal Fellowship co-financed by the EU Social Funds. C.V. thanks to CM for a research grant.

\section{Notes and references}

1 (a) M. R. Wasielewski, Chem. Rev., 1992, 92, 435; (b) D. Gust, T. A. Moore and A. L. Moore, Acc. Chem. Res., 2001, 34, 40.

2 (a) D. M. Guldi, N. Martín, ed., Fullerenes: From Synthesis to Optoelectronic Properties; Kluwer Academic Publishers: Dordrecht, The Netherlands, 2002; (b) F. Langa, J.-F. Nierengarten, ed., Fullerenes. Principles and Applications, RSC, Cambridge, UK, 2007; (c) N. Martín, Chem. Commun., 2006, 2093.

3 D. M. Guldi and M. Prato, Acc. Chem. Res., 2000, 33, 695.

4 (a) G. Accorsi and N. Armaroli, J. Phys. Chem. C, 2010, 114, 1385; (b) D. M. Guldi, G. M. Aminur Rahman, V. Sgobba and C. Ehli, Chem. Soc. Rev., 2006, 35, 471.

5 As representative examples of $\mathrm{D}_{1}-\mathrm{D}_{2}-\mathrm{A}$ triads, see: $(a) \mathrm{B}$. M. Illescas, J. Santos, M. Wielopolski, C. M. Atienza, N. Martín and D. M. Guldi, Chem. Commun., 2009, 5374; (b) H. Imahori, K. Tamaki, D. M. Guldi, C. Luo, M. Fujitsuka, O. Ito, Y. Sakata and S. Fukuzumi, J. Am. Chem. Soc., 2001, 123, 2607; (c) P. A. Liddell, D. Kuciauskas, J. P. Sumida, B. Nash, D. Nguyen,
A. L. Moore, T. A. Moore and D. Gust, J. Am. Chem. Soc., 1997, 119,1400 .

6 (a) C. A. Wijesinghe, M. E. El-Khouly, J. D. Blakemore, M. E. Melvin Zandler, S. Fukuzumi and F. D'Souza, Chem. Commun., 2010, 46, 3301; (b) D. Gonzalez-Rodriguez, E. Carbonell, G. de Miguel Rojas, C. Atienza Castellanos, D. M. Guldi and T. Torres, J. Am. Chem. Soc., 2010, 132, 16488.

7 M. A. Fazio, O. P. Lee and D. I. Schuster, Org. Lett., 2008, 10, 4979.

8 Compound 1 is formed in moderate yield (40\%). Since typical clickchemistry reactions take place with high yields, this result could be accounted for by the competition between the cycloaddition reaction of the azide derivative on the terminal alkyne group and on the fullerene units. Nevertheless, in order to minimize this competitive process, the reaction is carried out at room temperature. See supporting information $\uparrow$.

9 (a) J. L. Delgado, F. Cardinali, E. Espíldora, M. R. Torres, F. Langa and N. Martín, Org. Lett., 2008, 10, 3705; (b) J. L. Delgado, F. Oswald, F. Cardinali, F. Langa and N. Martín, J. Org. Chem., 2008, 73, 3184; (c) J. L. Delgado, E. Espíldora, M. Liedtke, A. Sperlich, D. Rauh, A. Baumann, C. Deibel, V. Dyakonov and N. Martín, Chem.- Eur. J., 2009, 15, 13474.

10 (a) M. Maggini, G. Scorrano and M. Prato, J. Am. Chem. Soc., 1993, 115, 9798; (b) M. Prato and M. Maggini, Acc. Chem. Res., 1998, 31, 519; (c) N. Tagmatarchis and M. Prato, Synlett, 2003, 768.

11 The chemical structure of 1 was confirmed by NMR, HPLC, and MS measurements $\left(\mathrm{m} / \mathrm{z}\right.$ calculated for $\mathrm{C}_{210} \mathrm{H}_{85} \mathrm{~N}_{11} \mathrm{O}_{2} \mathrm{Zn} 2858.6$ [M], found $2859.7[\mathrm{M}+1])$. See supporting information. $\dagger$ F For some examples on related $\mathrm{Zn}-\mathrm{C}_{60}$ dyads, see: (a) J. Iehl, R. Pereira de Freitas, B. Delavaux-Nicot and J.-F. Nierengarten, Chem. Commun., 2008, 2450; (b) M. A. Fazio, O. P. Lee and D. I. Schuster, Org. Lett., 2008, 10, 4979; (c) J. Iehl, I. Osinska, R. Louis, M. Holler and J.-F. Nierengarten, Tetrahedron Lett., 2009, 50, 2245; (d) J. Iehl, M. Vartanian, M. Holler, J.-F. Nierengarten, B. Delavaux-Nicot, J.-M. Strub, A. Van Dorsselaer, Y. Wu, J. Mohanraj, K. Yoosaf and N. Armaroli, J. Mater. Chem., 2011, 21, 1562.

12 Only recently good control of the site-, regio-, diastereo- and, enantioselectivity on $\mathrm{C}_{70}$ has been reported. See: E. E. Maroto, A. de Cozar, S. Filippone, A. Martín-Domenech, M. Súarez, F. P. Cossío and N. Martín, Angew. Chem., Int. Ed., 2011, 50, 6060.

13 (a) Q. Xie, E. Pérez-Cordero and L. Echegoyen, J. Am. Chem. Soc., 1992, 114, 3978; (b) L. Echegoyen and L. E. Echegoyen, Acc. Chem. Res., 1998, 31, 593; (c) J.-F. Nierengarten, A. Herrmann, R. R. Tykwinski, M. Riittimann, F. Diederich, C. Boudon, J.-P. Gisselbrecht and M. Gross, Helv. Chim. Acta, 1997, 80, 293.

14 (a) For a recent review, see: J. L. Delgado, N. Martín, P. de la Cruz, F. Langa, Chem. Soc. Rev., DOI: 10.1039/C1CS15105C; (b) J. L. Delgado, P. de la Cruz, V. López-Arza, F. Langa, D. B. Kimball, M. M. Haley, Y. Araki and O. Ito, J. Org. Chem., 2004, 69, 2661; (c) J. L. Delgado, P. de la Cruz, V. López-Arza and F. Langa, Tetrahedron Lett., 2004, 45, 1651; (d) F. Langa, P. de la Cruz, E. Espildora, A. de la Hoz, J. L. Bourdelande, L. Sanchez and N. Martín, J. Org. Chem., 2001, 66, 5033.

15 (a) M. Z. Hoffmann, F. Bolletta, L. Moggi and G. L. Hug, J. Phys. Chem. Ref. Data, 1989, 18, 219; (b) J. Rodriguez, C. Kirmaier and D. Holten, J. Am. Chem. Soc., 1989, 111, 6500; (c) S. L. Murov, I. Carmichael, G. L. Hug, Handbook of Photochemistry; Marcel Dekker Inc.; New York, 1993; (d) K. Kalyanasundaram, Photochemistry of Polypyridine and Porphyrin Complexes; Academic Press; London, 1992.

16 (a) L. Pekkarimen and H. Linschitz, J. Am. Chem. Soc., 1960, 82, 2407; (b) W. A. Lee, M. Graetzel and K. Kalyanasundaram, Chem. Phys. Lett., 1984, 107, 308.

17 (a) N. M. Dimitrijevic and P. V. Kamat, J. Phys. Chem., 1992, 96, 4811; (b) D. M. Guldi, P. V. Kamat, In Chemistry, Physics and Technology; K. M. Kadish, R. S. Ruoff, ed.; John Wiley and Sons: New York, 2000, p 225-282; (c) D. M. Guldi and M. Prato, Acc. Chem. Res., 2000, 33, 695.

18 (a) M. R. Wasielewski, M. P. O'Neil, K. R. Lykke, M. J. Pellin and D. M. Gruen, J. Am. Chem. Soc., 1991, 113, 2774; (b) K. Tanigaki, T. W. Ebbesen and S. Kuroshima, Chem. Phys. Lett., 1991, 185, 189; (c) H. T. Etheridge and R. B. Weisman, J. Phys. Chem., 1995, 99, 2782; (d) T. Nojiri, A. Watanabe and O. Ito, J. Phys. Chem. A, 1998, 102, 5215 .

19 S. Nonell, J. W. Arbogast and C. S. Foote, J. Phys. Chem., 1992, 96, 4169. 
20 (a) Z. Gasyna, W. R. Browett and M. Stillman, Inorg. Chem., 1985, 24, 2440; (b) D. M. Guldi, A. Hirsch, M. Scheloske, E. Dietel, A. Troisi, F. Zerbetto and M. Prato, Chem.-Eur. J., 2003, 9, 4968.

21 (a) D. I. Schuster, P. Cheng, P. D. Jarowski, D. M. Guldi, C. Luo, L. Echegoyen, S. Pyo, A. R. Holzwarth, S. E. Braslavsky, R. M. Williams and G. Klihm, J. Am. Chem. Soc., 2004, 126, 7257; (b) A. S. D. Sandanayaka, H. Sasabe, Y. Araki, Y. Furusho, O. Ito and T. Takata, J. Phys. Chem. A, 2004, 108, 5145; (c) D. I. Schuster, S. MacMahon, D. M. Guldi, L. Echegoyen and S. E. Braslavsky, Tetrahedron, 2006, 62, 1928; (d) F. Wessendorf, J.-F. Gnichwitz, G. H. Sarova, K. Hager, U. Hartnagel, D. M. Guldi and A. Hirsch, J. Am. Chem. Soc., 2007, 129, 16057; (e) K. Maurer, B. Grimm, F. Wessendorf, K. Hartnagel, D. M. Guldi and A. Hirsch, Eur. J. Org. Chem., 2010, 5010; (f) F. Wessendorf, B. Grimm, D. M. Guldi and A. Hirsch, J. Am. Chem. Soc., 2010, 132, 10786.

22 Such a nearly simultaneous formation of the $\mathrm{C}_{60} \pi$-radical anion and the $\mathrm{C}_{70} \pi$-radical anion can only be rationalized on the basis that the $\mathrm{ZnP}$ singlet excited state reduces the adjacent $\mathrm{C}_{60}$, while the $\mathrm{C}_{70}$ singlet excited state is reduced by the $\mathrm{ZnP}$ singlet ground state.

23 D. R. Lawson, D. L. Feldhein, C. A. Foss, P. K. Dorhout, C. M. Elliott, C. R. Martin and B. Parkinson, J. Phys. Chem., 1992, 96, 7175 .

24 The $\mathrm{ZnP}$ centered fluorescence is in the $\mathrm{ZnP}-\mathrm{C}_{60}-\mathrm{C}_{70}$ conjugate (1) quenched by a factor of more than 10 . 